\title{
Novel Betaines of the Hexaalkylguanidinio-carboxylate Type
}

\author{
Matthias Walter and Gerhard Maas \\ Institute for Organic Chemistry I, University of Ulm, Albert-Einstein-Allee 11, 89081 Ulm, \\ Germany
}

Reprint requests to Prof. Dr. Gerhard Maas. Fax: 49 (0)731-5022803.

E-mail: gerhard.maas@uni-ulm.de

Z. Naturforsch. 2009, 64b, 1617 -1624; received September 29, 2009

Dedicated to Professor Hubert Schmidbaur on the occasion of his $75^{\text {th }}$ birthday

Betaines 7a, b and 8a, $\mathbf{b}$ have been prepared from 3- and 4-piperidinecarboxylic acid and $N, N, N^{\prime}, N^{\prime}$-tetraalkyl-chloroformamidinium chlorides via the corresponding methyl esters. These betaines are highly hygroscopic, thermally very stable, and, with the exception of $\mathbf{7 b}$, have rather low melting points. They undergo a surprisingly facile alkaline cleavage of the hexaalkylguanidinium moiety. They react with dichloromethane by a twofold nucleophilic substitution to form methylene dicarboxylates such as 11. The NMR $\left({ }^{1} \mathrm{H},{ }^{13} \mathrm{C}\right)$ data of betaines $\mathbf{7}$ and $\mathbf{8}$ are discussed.

Key words: Betaines, Guanidinium, Nipecotic Acid, Isonipecotic Acid, Piperidinecarboxylic Acids

\section{Introduction}

Betaines are zwitterionic compounds containing a positively charged onium group, which does not bear a hydrogen atom, and a negatively charged functional group not adjacent to the cationic function. They have been named after (trimethylammonio)acetate ("betaine", nowadays called glycine betaine) (Fig. 1, A), a common naturally occurring compound which is found in significant amounts in, e.g., sugar beet, sugar beet molasses, and in shellfish [1]. Glycine betaine and related betaines have various functions in biological systems; for example, they are organic osmolytes, which protect cells against osmotic stress and dehydration [2], and act as methyl donors. Glycine betaine and other $N$-peralkylated glycinates are among the socalled compatible solutes, which can enhance the efficiency of the polymerase chain reaction by destabilization of the DNA duplex and facilitation of the initial strand dissociation process $[2,3]$.

Due to their ampholytic character and the resulting physico-chemical properties, the low toxicity, mild-onskin properties and biodegradability, natural betaine $\mathbf{A}$ and synthetic betaines such as cocamidopropyl betaine (B) find wide application in shampoos, hand soaps, hair conditioners, and cosmetic formulations $[4,5]$. Synthetic betaines, such as $\mathbf{B}$ and analogous sulfobetaines, are amphotenside ingredients in washing powders [6].
Given our interest in the properties of hexaalkylguanidinium salts, in particular those which are ionic liquids [7], we became attracted to the so far unknown betaines of the hexaalkylguanidiniocarboxylate type. When designed appropriately, such compounds could have properties similar to those of hexaalkylguanidinium-based ionic liquids, such as low melting point, high thermal stability and low vapor pressure. In addition, the zwitterionic character of the molecule and the presence of the carboxylate function in particular could endow these compounds with a reactivity which is reminescent of task-specific ionic liquids. A number of betaines, mainly with imidazolium, tetraalkylammonium and pyridinium as the cationic group and sulfonate or carboxylate as the anionic site, have recently been studied as a new class of ion-conductive matrices for electrochemical devices [8,9]. As target molecules, we chose the hexaalkylguanidinio-carboxylates $\mathbf{C}$ and D, which represent guanylated derivatives of the pharmaceutically relevant amino acids 3- and 4piperidinecarboxylic acid (nipecotic and isonipecotic acid), respectively. Sha and Liebscher [10] have recently prepared a range of hexaalkylguanidinium salts, which have the nitrogen atom of $\alpha$-aminoacid esters incorporated into the guanidinium group; however, they did not proceed further to generate betaines by converting the carboxylic ester into a carboxylate function. 
<smiles>C[N+](C)(C)CC(=O)[O-]</smiles>

A<smiles>C[N+](C)(CCNC(=O)[CH]CCC(=O)[O-])CC(=O)[O-]</smiles>

B

\section{Results and Discussion}

\section{Synthesis of guanidinio-carboxylates 7 and 8}

The synthesis of betaines 7 and $\mathbf{8}$ (Scheme 1) employs an established method for the preparation of hexasubstituted guanidinium salts, namely the reaction of a sec-amine with an $N, N, N^{\prime}, N^{\prime}$-tetrasubstituted chloroamidinium salt, readily prepared from the corresponding urea and phosgene or oxalyl chloride and used without purification $[11,12]$. Commercially available ( \pm )-nipecotic acid (1a) and isonipecotic acid (1b) were first converted into the corresponding methyl esters $\mathbf{2 a}, \mathbf{b}$ by treatment with $\mathrm{SOCl}_{2} /$ methanol, as described in the literature $[13,14]$. These piperidinecarboxylic esters were then guanylated with chloroformamidinium salts $\mathbf{3}$ and $\mathbf{4}$ in the presence of triethylamine to give the guanidinium salts $5 \mathbf{a}, \mathbf{b}$ and $\mathbf{6 a}, \mathbf{b}$, respectively. The guanidinium salts could not be isolated in pure form, because the separation from also formed triethylammonium chloride was incomplete. While this separation in other cases succeeds by neutralization of the ammonium salt with aqueous $\mathrm{NaOH}$, we found that guanidinium salts $\mathbf{5}$ and $\mathbf{6}$ suffer rapid ester cleavage when exposed to $2 \mathrm{M}$ aqueous $\mathrm{NaOH}$ to provide the desired betaines $7 \mathbf{a}, \mathbf{b}$ and $\mathbf{8 a}, \mathbf{b}$, respectively.

Hexaalkylguanidinium salts are normally rather stable to hydroxide ions in dilute solution at r. t. [15, 16]. If at all, alkaline hydrolysis occurs at a significant rate only at elevated temperature: while the kinetics were studied for hexamethylguanidinium perchlorate at $60{ }^{\circ} \mathrm{C}$ [17], hexaalkylguanidinium salts bearing longer alkyl chains were reported to be stable to equimolar $\mathrm{KOH}$ at $60-80{ }^{\circ} \mathrm{C}$ [16]. Therefore, we were surprised to observe that betaines $\mathbf{7}$ and $\mathbf{8}$ underwent slow cleavage of the guanidinium function when exposed to $2 \mathrm{M}$ aqueous $\mathrm{NaOH}$ at r.t. The scenario is shown exemplarily for betaine $\mathbf{7 b}$ in Scheme 2. In agreement with the unsymmetrical constitution of the guanidinium group, hydrolytic cleavage proceeded in two<smiles>[R]N([R])C(N([R])[R])N1CCCC(C(=O)[O-])C1</smiles>

C: $3-\mathrm{COO}^{-}$

D: $4-\mathrm{COO}^{-}$
Fig. 1. Glycine betaine (A), cocamidopropyl betaine $(\mathbf{B}, n=11)$, and novel betaines $\mathbf{C}$ and $\mathbf{D}$.

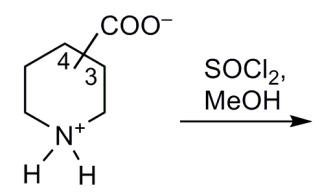

1a: $3-\mathrm{COO}^{-}$ 1b: $4-\mathrm{COO}^{-}$<smiles>[CH-][NH+]1CCCC(C(=O)OC)CC1</smiles>

2a: 3-COOMe 2b: 4-COOMe

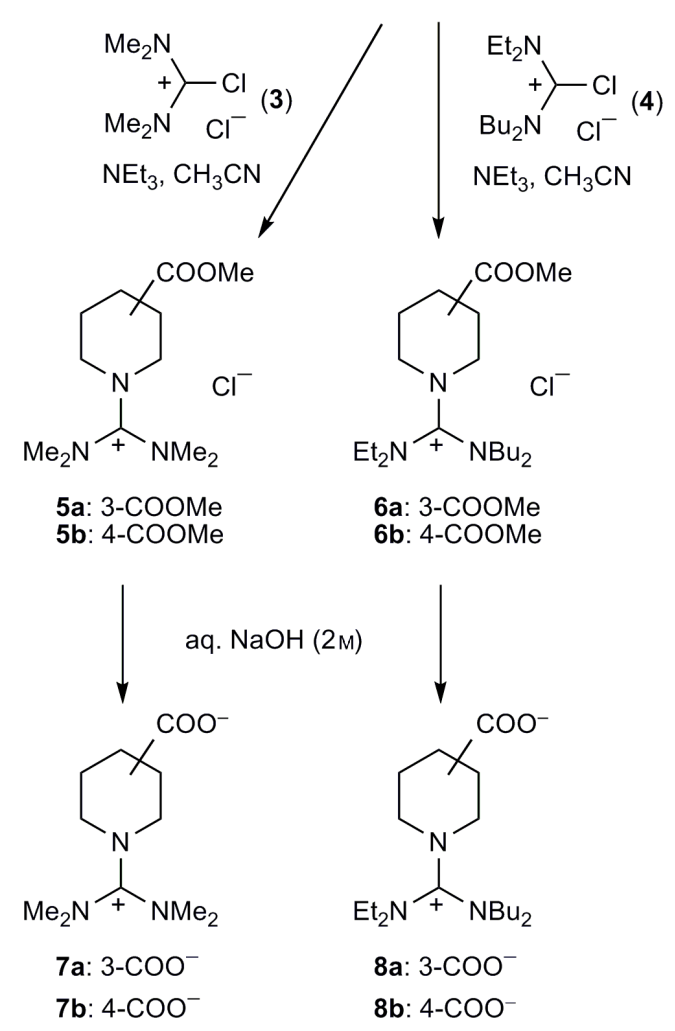

Scheme 1. Synthesis of betaines $\mathbf{7}$ and $\mathbf{8}$.

directions, one leading to $N$-dimethylaminocarbonyl4-piperidinecarboxylic acid (9) and dimethylamine, the other to tetramethylurea and aminoacid $\mathbf{1 b}$. The two urea derivatives were formed in a $77: 23$ ratio according to ${ }^{1} \mathrm{H}$ NMR spectroscopy. Fortunately, the 


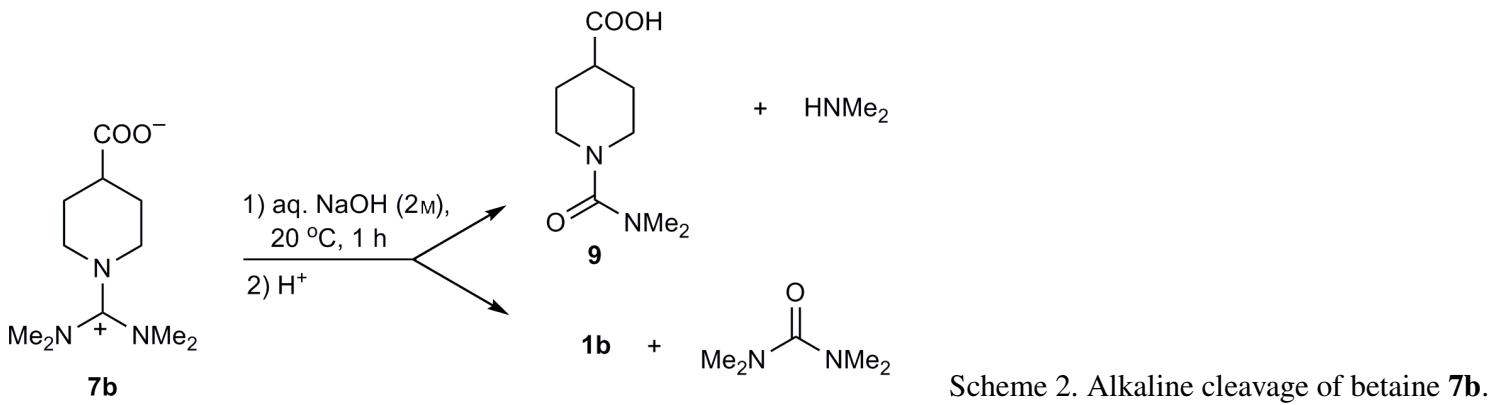

alkaline cleavage of betaines $\mathbf{7}$ and $\mathbf{8}$ is slow under the conditions for the generation of the betaines from esters 5 and 6, so that the betaines can be obtained selectively under controlled reaction conditions.

In contrast to betaines $\mathbf{7}$ and $\mathbf{8}$, the related guanidinium chloride $\mathbf{1 0}$ (Fig. 2), prepared by analogy to a literature method [12b], shows the typical behavior of simple hexaalkylguanidinium salts toward bases: it appears to be stable to an excess of dilute aqueous $\mathrm{NaOH}$ at r.t., but is decomposed slowly in concentrated aqueous $\mathrm{NaOH}$.<smiles>CN(C)C(N1CCCCC1)=[N+]([O-])[O-]</smiles>

10
Fig. 2.

Notably, betaines $\mathbf{7}$ and $\mathbf{8}$ cannot be obtained by direct reaction of piperidinecarboxylic acids $\mathbf{1}$ with the chloroformamidinium salts $\mathbf{3}$ and $\mathbf{4}$. The reaction of 1b with 3 or 4 in the presence of two equivalents of triethylamine gave rise to the formation of the corresponding tetraalkylurea besides triethylammonium chloride. Very likely, aminoacid $\mathbf{1 b}$ adds to the chloroformamidinium salts through the carboxylate function, and the resulting addition product is then cleaved to yield the tetraalkylurea and the acid chloride of $\mathbf{1 b}$, which probably forms oligomers under the reaction conditions. The ability of chloroamidinium salts to activate carboxylic acids $[12,18]$ and to undergo chlorination reactions [12] is known.

\section{Properties of betaines 7 and 8}

Betaines $\mathbf{7}$ and $\mathbf{8}$ are water-soluble and water-stable solids which are extremely hygroscopic and deliquesce within hours or days if not kept in a rigorously dry environment. For example, we observed that $7 \mathbf{a}, \mathbf{b}$ picked up one equivalent of water within $3-6 \mathrm{~h}$ of exposure to laboratory air and 5-6 equivalents of

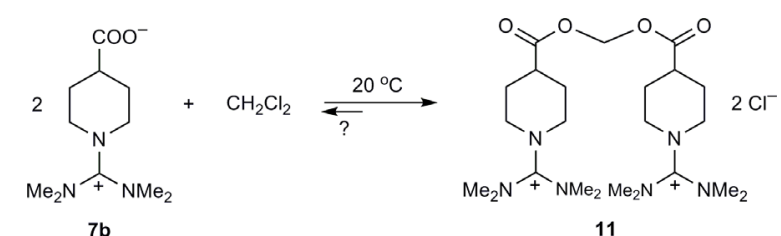

Scheme 3 . Reaction of betaine $\mathbf{7 b}$ with dichloromethane.

water during $10 \mathrm{~d}$.

In contrast to the solubility in water and acetonitrile, betaines $\mathbf{7}$ and $\mathbf{8}$ are almost insoluble in dichloromethane, but surprisingly they undergo a chemical reaction with this solvent. For example, when a suspension of betaine $\mathbf{7 b}$ in $\mathrm{CH}_{2} \mathrm{Cl}_{2}$ was stirred for several hours, a part of the solid had disappeared. Analysis of the dichloromethane phase indicated the formation of a new product, which was identified as the dicationic salt 11 (Scheme 3 ) by its NMR data and an ESI-MS ([cation] ${ }^{2+} \mathrm{Cl}^{-}$as the base peak). This reaction appears to be an equilibrium reaction which proceeded only to a conversion of $85 \%$ of $7 \mathbf{b}$ after $72 \mathrm{~h}(60 \%$ conversion after $3 \mathrm{~h}$ ). Obviously, the methylene dicarboxylate 11 results from a twofold nucleophilic substitution reaction at the $\mathrm{CH}_{2} \mathrm{Cl}_{2}$ molecule. The remarkably smooth formation of $\mathbf{1 1}$ may be attributed to an exceptionally high nucleophilicity of the carboxylate group in betaine $7 \mathbf{b}$ due to the absence of ion pairing with a cationic counterion. Kinetic investigations have shown that $\mathrm{CH}_{2} \mathrm{Cl}_{2}$ is much more reluctant to an $\mathrm{S}_{\mathrm{N}} 2$ reaction than dibromo- and diiodomethane [19]. Furthermore, the synthesis of methylene diacetate [20] and methylene dicarboxylates [21] usually requires much harsher reactions than in our case, e. $g$. by heating of $\mathrm{CH}_{2} \mathrm{X}_{2}$ $(\mathrm{X}=\mathrm{Br}, \mathrm{I})$ with an excess of KOAc in refluxing acetic acid containing acetic anhydride [19].

\section{Thermal behavior}

Because of partial hydrolysis at elevated temperatures (see Experimental Section), an exact description 
Table $1 .{ }^{13} \mathrm{C}$ chemical shifts ( $\delta$ values in ppm, $\mathrm{D}_{2} \mathrm{O}$ as solvent) for guanidinium betaines $\mathbf{7 b}$ and $\mathbf{8 b}$, compared with their precursors.

\begin{tabular}{|c|c|c|c|c|c|c|}
\hline & $1 \mathbf{b}$ & $2 \mathbf{b}$ & $5 \mathbf{b}$ & $7 \mathbf{b}$ & $6 \mathbf{b}$ & $8 \mathbf{b}$ \\
\hline $\mathrm{C}-2$ & 43.47 & 43.02 & $47.35,47.60$ & $47.98,48.30$ & $48.09,48.14,48.20,48.24$ & $48.70,48.76,48.82,48.85$ \\
\hline $\mathrm{C}-3$ & 25.64 & 24.37 & $26.49,27.50$ & $27.71,28.90$ & $26.29,26.40,27.25,27.40$ & $27.46,27.59,28.62,28.72$ \\
\hline C-4 & 41.42 & 38.05 & 40.02 & 43.42 & 40.10 & $43.62,43.64$ \\
\hline $\mathrm{COO}^{-}$ & 182.15 & & & 183.19 & & $183.23,183.27$ \\
\hline $\mathrm{COOCH}_{3}$ & & $176.21,52.65$ & $177.32,52.43$ & & $177.18 / 177.21,52.59$ & \\
\hline guanidinium- $\mathrm{CN}_{3}$ & & & 162.79 & 162.90 & $163.07,163.09$ & $163.01,163.07$ \\
\hline $\mathrm{NCH}_{3}$ & & & $\begin{array}{l}39.13 \\
39.43(2 \mathrm{C}) \\
39.78\end{array}$ & $\begin{array}{l}39.10 \\
39.41(2 \mathrm{C}) \\
39.92\end{array}$ & & \\
\hline $\mathrm{NCH}_{2} \mathrm{CH}_{3}$ & & & & & $\begin{array}{l}\mathrm{CH}_{3}: 11.96,12.24(3 \mathrm{C}) \\
\mathrm{CH}_{2}: 43.06,43.79(2 \mathrm{C}), 44.12\end{array}$ & $\begin{array}{l}\mathrm{CH}_{3}: 11.91,12.21(3 \mathrm{C}) ; \\
\mathrm{CH}_{2}: 43.06,43.79(2 \mathrm{C}), 44.12\end{array}$ \\
\hline$N$-butyl & & & & & $\begin{array}{l}\mathrm{C}-1: 48.66,49.12,49.58,49.76 \text {; } \\
\mathrm{C}-2: 28.81,29.04,29.08,29.12 ; \\
\mathrm{C}-3: 19.52,19.59 ; \\
\mathrm{CH}_{3}: 13.02,13.05 \text { (3 C) }\end{array}$ & $\begin{array}{l}\mathrm{C}-1: 48.55,49.11,49.38,49.72 ; \\
\mathrm{C}-2: 28.80,29.06,29.10(2 \mathrm{C}) \\
\mathrm{C}-3: 19.50,19.58 ; \\
\mathrm{CH}_{3}: 12.97,13.06(3 \mathrm{C})\end{array}$ \\
\hline
\end{tabular}

of the thermally induced phase changes of betaines 7 and $\mathbf{8}$ by differential scanning calorimetry could not be obtained. Qualitative data could be obtained, however, by heating the betaines under vacuum (0.01 mbar). The powdery solid of $7 \mathbf{a}$ becomes sticky at about $80{ }^{\circ} \mathrm{C}$, is transformed into a yellow-orange glass at $100{ }^{\circ} \mathrm{C}$ and into a very viscous oil at about $120^{\circ} \mathrm{C}$. On cooling, a glass is formed again around $100{ }^{\circ} \mathrm{C}$ and is stable on further cooling back to $20^{\circ} \mathrm{C}$. Dissolution of the glass in acetonitrile and evaporation of the solvent reconstitutes the powdery solid of $7 \mathbf{a}$. The symmetrical betaine $\mathbf{7 b}$, on the other hand, remains unchanged when heated to $160{ }^{\circ} \mathrm{C}$. As expected, betaines 8a, b, featuring longer alkyl chains and an unsymmetrical substitution at the guanidinium moiety, have lower melting points than betaines $7 \mathbf{a}, \mathbf{b}$. Betaine 8a forms a highly viscous orange-brownish oil already at $40{ }^{\circ} \mathrm{C}$ and a glass on cooling back to $20{ }^{\circ} \mathrm{C}$. Betaine $8 \mathrm{~b}$ forms a glass at $60{ }^{\circ} \mathrm{C}$ and a highly viscous yellowish oil at about $80{ }^{\circ} \mathrm{C}$; a glass is formed again when the temperature is lowered to $60{ }^{\circ} \mathrm{C}$. In the first two heating cycles of a DSC measurement, a glass transition temperature $\left(T_{\mathrm{g}}\right)$ was registered at $23-30{ }^{\circ} \mathrm{C}$ for $\mathbf{8 b}$. In summary, all betaines except $\mathbf{7 b}$ have lower melting points than reported for a wide range of other carboxylate and sulfonate betaines [9b].

The thermal stability of the betaines was determined by thermogravimetric analyses (TGA). Decomposition temperatures $\left(T_{\mathrm{dec}}\right)$, defined as the temperature of maximum decomposition rate, were registered at 283 (7a), 331 (7b), $269(\mathbf{8 a})$, and $300{ }^{\circ} \mathrm{C}(\mathbf{8 b})$. However, noticeable mass loss occurred already at temperatures lower by $60-80{ }^{\circ} \mathrm{C}$. The TGA curves gave no hints to a con- trolled, stepwise thermal degradation of the betaines.

\section{NMR spectra}

For steric reasons, hexa-substituted guanidinium ions exist in a propeller-like configuration both in solution [22] and in the solid state [23]. Charge delocalization gives rise to a partial double bond character at the three $\mathrm{C}-\mathrm{N}$ bonds, with rotation barriers that prevent free rotation at r.t. As a consequence, the NMR spectra usually become more complex [9, 22, 23f]. This is also the case for betaines $\mathbf{7}$ and $\mathbf{8}$ and their precursors, methyl esters 5 and 6. An illustration is given in Table 1 , where the ${ }^{13} \mathrm{C}$ chemical shifts of the 4 substituted betaines $\mathbf{7 b}$ and $\mathbf{8 b}$ and methyl esters $\mathbf{5 b}$ and $\mathbf{6 b}$ are compared with those of the piperidine-4carboxylates $\mathbf{1 b}$ and $\mathbf{2 b}$. It can be seen that all four $N$ methyl groups in the guanidinium systems $\mathbf{5 b}$ and $\mathbf{7 b}$ are magnetically non-equivalent, and that the ring carbon atoms C-2/6 as well as C-3/5 are diastereotopic. The suggested structures of $\mathbf{5}$ and $\mathbf{7}$ contain a piperidine ring in chair conformation (which is confirmed by analysis of the $\mathrm{H}, \mathrm{H}$ coupling constants in the ${ }^{1} \mathrm{H}$ NMR spectra, see Experimental Section) and an attached tetraalkylamidinium moiety the $\mathrm{N}-\mathrm{C}-\mathrm{N}$ plane

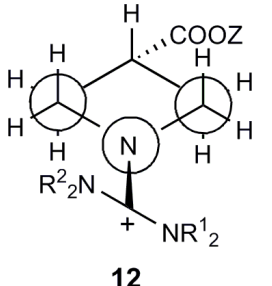

Fig. 3. Suggested structure of guanidinium systems 5 and 7 (Newman projection along $\mathrm{C}-2(6)-\mathrm{C}-3(5)$ bonds). 
of which is permanently twisted against the $\mathrm{C}-\mathrm{N}-\mathrm{C}$ plane of the piperidine ring (Fig. 3). For the unsymmetrically substituted guanidinium systems $\mathbf{6 b}$ and $\mathbf{8 b}$, two orientations of the amidinium moiety $\mathrm{R}^{1}{ }_{2} \mathrm{~N}-\mathrm{C}$ $\mathrm{NR}^{2}{ }_{2}$ relative to the 4 -substituted piperidine ring are possible. The additional isomer gives rise to a second set of signals in the NMR spectra. While the two signal sets can be distinguished in the ${ }^{13} \mathrm{C}$ spectra (e. g., $\mathrm{C}-2, \mathrm{C}-3$, and most $N$-ethyl and $N$-butyl carbon atoms give rise to four signals), the ${ }^{1} \mathrm{H}$ NMR spectra can no longer be analyzed in detail due to extensive overlap of the multiplet signals. Analogous considerations apply for the derivatives of piperidine-3-carboxylic acids, $5 \mathbf{a}-\mathbf{8 a}$.

\section{Conclusion}

Hexaalkylguanidinio-carboxylates $\mathbf{7}$ and $\mathbf{8}$ represent a new type of betaines. Three of them $(\mathbf{7 a}, \mathbf{8 a}, \mathbf{8 b})$ show markedly lower melting points than many known betaines with imidazolium, ammonium or pyridinium as the cationic moiety and carboxylate or sulfonate as the anionic part. With a solid $\rightarrow$ liquid phase transition below $100{ }^{\circ} \mathrm{C}$, betaines $\mathbf{8 a}, \mathbf{b}$ fullfill the definition of ionic liquids ("zwitterionic ionic liquids" $[9 b, d]$ ). Two remarkable chemical properties of the new betaines have been observed. One is the unexpectedly facile alkaline cleavage of the guanidinium moiety, the other one is the high nucleophilicity of the carboxylate function which allows the formation of a methylene dicarboxylate by twofold nucleophilic substitution of dichloromethane.

\section{Experimental Section}

\section{General information}

NMR spectra were recorded using a Bruker DRX 400 spectrometer $\left({ }^{1} \mathrm{H}: 400.13 \mathrm{MHz},{ }^{13} \mathrm{C}: 100.61 \mathrm{MHz}\right) .{ }^{1} \mathrm{H}$ NMR spectra were referenced to the residual proton signal of the solvent $\left[\delta_{\mathrm{H}}\left(\mathrm{D}_{2} \mathrm{O}\right)=4.79 \mathrm{ppm}\right] ; \mathrm{m}_{\mathrm{c}}=$ centered multiplet. Signal assignments were based on H,H (COSY, TOCSY) and $\mathrm{C}, \mathrm{H}$ correlation spectra (HSQC, HMBC). Mass spectra (ESI): Micromass UK, ZMD.

Piperidinecarboxylic esters ( \pm )-2a [13] and 2b [14] were prepared by published procedures. Acetonitrile solutions of chloroformamidinium chlorides $\mathbf{3}$ and $\mathbf{4}$ were supplied by Prof. W. Kantlehner (Hochschule Aalen).

\section{1-[Bis(dimethylamino)methylene]-3-(methoxycarbonyl)- piperidinium chloride (5a); typical procedure}

Methyl piperidine-3-carboxylate hydrochloride (2a, $0.83 \mathrm{~g}, 4.6 \mathrm{mmol}$ ) and a solution of $N, N, N^{\prime}, N^{\prime}$-tetramethyl- chloroamidinium chloride (3) in acetonitrile $(0.91 \mathrm{~mol} / \mathrm{kg}$, $5.83 \mathrm{~g}, 5.3 \mathrm{mmol}$ of 3 ) were placed in a round-bottom flask equipped with a gas inlet and flushed with argon. Dry triethylamine, dried over $\mathrm{KOH}$ (1.5 mL, $1.09 \mathrm{~g}, 10.8 \mathrm{mmol}$ ), was slowly added while cooling the flask in a water bath. The reaction mixture was allowed to stir for $72 \mathrm{~h}$, and the precipitated triethylammonium chloride was filtered off under an argon atmosphere. Besides small amounts of 3 and tetramethylurea, the solution still contained some triethylammonium chloride, which could not be separated from product 5a, and was therefore used without further purification in the next step.

Guanidinium salts $\mathbf{5 b}, \mathbf{6} \mathbf{a}$, and $\mathbf{6 b}$ were prepared analogously.

NMR data of salt 5a: ${ }^{1} \mathrm{H}$ NMR $\left(\mathrm{D}_{2} \mathrm{O}\right): \delta=1.61-2.31$ (several m, $4 \mathrm{H}, 4-\mathrm{H}_{2}, 5-\mathrm{H}_{2}$ ), $2.67-3.69$ (several m, $17 \mathrm{H}, 2$ $\left.\mathrm{H}_{2}, 3-\mathrm{H}, 6-\mathrm{H}_{2}, \mathrm{~N}\left(\mathrm{CH}_{3}\right)_{2}\right), 3.78\left(\mathrm{~s}, 3 \mathrm{H}, \mathrm{OCH}_{3}\right) .-{ }^{13} \mathrm{C} \mathrm{NMR}$ $\left(\mathrm{D}_{2} \mathrm{O}\right): \delta=22.91$ (C-5), 25.70, 26.44 (C-4); 39.23, 39.53, 39.70, $39.89\left(4 \mathrm{NCH}_{3}\right)$; 41.80, 43.63 (C-3); 48.46, 48.62 (C-6); 49.43, $49.78(\mathrm{C}-2) ; 52.59\left(\mathrm{OCH}_{3}\right), 163.02\left(\mathrm{CN}_{3}\right)$, $175.80\left(\mathrm{COOCH}_{3}\right)$.

\section{1-[Bis(dimethylamino)methylene]-4-(methoxycarbonyl)- piperidinium chloride $(\mathbf{5 b})$}

Prepared from methyl piperidine-4-carboxylate hydrochloride (2b, $0.90 \mathrm{~g}, 5.0 \mathrm{mmol})$, salt 3 dissolved in acetonitrile $(0.91 \mathrm{~mol} / \mathrm{kg}, 7.50 \mathrm{~g}, 6.8 \mathrm{mmol})$ and triethylamine (1.6 mL, $1.16 \mathrm{~g}, 11.5 \mathrm{mmol}) .-{ }^{1} \mathrm{H}$ NMR $\left(\mathrm{D}_{2} \mathrm{O}\right): \delta=1.66$ (dddd, ${ }^{2} J=13 \mathrm{~Hz},{ }^{3} J=11,10$ and $4 \mathrm{~Hz}, 1 \mathrm{H}, \mathrm{NCH}_{2} \mathrm{CH}^{\mathrm{ax}}$ ), 1.85 (dddd, ${ }^{2} J=13 \mathrm{~Hz},{ }^{3} J=11,10$ and $4 \mathrm{~Hz}, 1 \mathrm{H}$, $\mathrm{NCH}_{2} \mathrm{CH}^{\mathrm{ax}}$ ), 2.00 (dddd, ${ }^{2} J=13 \mathrm{~Hz},{ }^{3} J=4,4$ and $3 \mathrm{~Hz}$, $1 \mathrm{H}, \mathrm{NCH}_{2} \mathrm{CH}^{\mathrm{eq}}$ ), 2.03 (dddd, ${ }^{2} J=13 \mathrm{~Hz},{ }^{3} J=4,4$ and $\left.3 \mathrm{~Hz}, 1 \mathrm{H}, \mathrm{NCH}_{2} \mathrm{CH}^{\mathrm{eq}}\right), 2.73\left(\mathrm{tt},{ }^{3} J=10\right.$ and $4 \mathrm{~Hz}, 1 \mathrm{H}$, ring-4-H); 2.88, 2.89, 2.90, $2.97\left(4 \mathrm{~s}\right.$, each $\left.3 \mathrm{H}, \mathrm{NCH}_{3}\right) ; 3.15$ (ddd, ${ }^{2} J=13 \mathrm{~Hz},{ }^{3} J=11$ and $3 \mathrm{~Hz}, 1 \mathrm{H}, \mathrm{NCH}^{\text {ax }}$ ), 3.21 (ddd, ${ }^{2} J=13 \mathrm{~Hz},{ }^{3} J=11$ and $\left.3 \mathrm{~Hz}, 1 \mathrm{H}, \mathrm{NCH}{ }^{\mathrm{ax}}\right), 3.42\left(\mathrm{ddd},{ }^{2} J=\right.$ $13 \mathrm{~Hz},{ }^{3} J=4$ and $\left.4 \mathrm{~Hz}, 1 \mathrm{H}, \mathrm{NCH}^{\mathrm{eq}}\right), 3.52\left(\mathrm{ddd},{ }^{2} J=13 \mathrm{~Hz}\right.$, ${ }^{3} J=4$ and $\left.4 \mathrm{~Hz}, 1 \mathrm{H}, \mathrm{NCH}{ }^{\mathrm{eq}}\right), 3.70\left(\mathrm{~s}, 3 \mathrm{H}, \mathrm{OCH}_{3}\right) \cdot-{ }^{13} \mathrm{C}$ NMR: Table 1.

\section{1-[(Dibutylamino $)($ diethylamino $)$ methylene $]-3-($ methoxy- carbonyl)piperidinium chloride (6a)}

Prepared from 2b $(0.90 \mathrm{~g}, 5.0 \mathrm{mmol})$, salt 4 dissolved in acetonitrile $(2.60 \mathrm{~mol} / \mathrm{kg}, 2.69 \mathrm{~g}, 7.0 \mathrm{mmol})$ and triethylamine $(1.6 \mathrm{~mL}, 1.16 \mathrm{~g}, 11.5 \mathrm{mmol})$ in dry acetonitrile $(10 \mathrm{~mL}) .-{ }^{1} \mathrm{H} \mathrm{NMR}\left(\mathrm{D}_{2} \mathrm{O}\right): \delta=0.91-1.00$ (m, $6 \mathrm{H}$, butyl$\left.\mathrm{CH}_{3}\right), 1.18-1.28\left(\mathrm{~m}, 6 \mathrm{H}, \mathrm{NCH}_{2} \mathrm{CH}_{3}\right), 1.32-1.42(\mathrm{~m}, 4 \mathrm{H}$, butyl-3- $\mathrm{H}_{2}$ ), $1.46-2.32$ (several $\mathrm{m}, 8 \mathrm{H}$, ring-4- and $5-\mathrm{H}_{2}$, butyl-2- $\mathrm{H}_{2}$ ), 2.68-3.76 (several $\mathrm{m}, 13 \mathrm{H}$, ring- $\mathrm{NCH}_{2} \mathrm{CH}$, ring-6- $\mathrm{H}_{2}$, butyl-1- $\left.\mathrm{H}_{2}, \mathrm{NCH}_{2} \mathrm{CH}_{3}\right), 3.79\left(\mathrm{~s}, 3 \mathrm{H}, \mathrm{OCH}_{3}\right)$.

1-[(Dibutylamino $)($ diethylamino $)$ methylene $]-4-($ methoxycarbonyl)piperidinium chloride $(\boldsymbol{6} \boldsymbol{b})$ 
Prepared from 2b $(0.90 \mathrm{~g}, 5.0 \mathrm{mmol})$, salt 4 dissolved in acetonitrile $(2.60 \mathrm{~mol} / \mathrm{kg}, 2.85 \mathrm{~g}, 7.4 \mathrm{mmol})$ and triethylamine $(1.6 \mathrm{~mL}, 1.16 \mathrm{~g}, 11.5 \mathrm{mmol})$ in dry acetonitrile $(10 \mathrm{~mL}) .-{ }^{1} \mathrm{H}$ NMR $\left(\mathrm{D}_{2} \mathrm{O}\right): \delta=0.93-1.00(2 \mathrm{t}, 6 \mathrm{H}$, butyl$\left.\mathrm{CH}_{3}\right), 1.20-1.25$ (2 q, $6 \mathrm{H}$, ethyl- $\left.\mathrm{CH}_{3}\right), 1.28-1.42(\mathrm{~m}, 4 \mathrm{H}$,

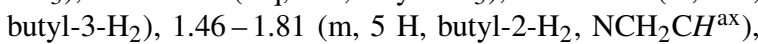
$1.97\left(\mathrm{~m}_{\mathrm{c}}, 1 \mathrm{H}, \mathrm{NCH}_{2} \mathrm{CH}^{\mathrm{ax}}\right), 2.12\left(\mathrm{~m}_{\mathrm{c}}, 2 \mathrm{H}, \mathrm{NCH}_{2} \mathrm{CH}^{\mathrm{eq}}\right)$, $2.81\left(\mathrm{~m}_{\mathrm{c}}, 1 \mathrm{H}\right.$, ring-4-H), $3.09-3.52\left(\mathrm{~m}, 11 \mathrm{H}\right.$, butyl- $\mathrm{NCH}_{2}$, ethyl- $\mathrm{NCH}_{2}, 3$ ring- $\left.\mathrm{NCH}_{2}\right), 3.62\left(\mathrm{~m}_{\mathrm{c}}, 1 \mathrm{H}\right.$, ring- $\left.\mathrm{NCH}^{\mathrm{eq}}\right)$, $3.79\left(\mathrm{~s}, 3 \mathrm{H}, \mathrm{OCH}_{3}\right) .-{ }^{13} \mathrm{C}$ NMR: Table 1.

\section{1-[Bis(dimethylamino)methylene]piperidinium 3-carboxyl- ate (7a); typical procedure}

The crude solution of ester $\mathbf{5 a}$ in acetonitrile (see above) was used. The solvent was evaporated at $0.01 \mathrm{mbar} / 35{ }^{\circ} \mathrm{C}$, and the solid residue was dissolved in demineralized water $(10 \mathrm{~mL})$. Aqueous $\mathrm{NaOH}(2 \mathrm{M})$ was added drop by drop until 5a was consumed completely $(3.9 \mathrm{~mL}$, reaction monitoring by ${ }^{1} \mathrm{H} \mathrm{NMR}$, disappearance of the ester signal at $\delta=3.78 \mathrm{ppm}$ ). Water and triethylamine were evaporated at $0.01 \mathrm{mbar} / 40{ }^{\circ} \mathrm{C}$, and the solid residue was dried at $0.01 \mathrm{mbar} / 60{ }^{\circ} \mathrm{C}$ during $5 \mathrm{~h}$. Betaine $7 \mathrm{a}$ was extracted with dry acetonitrile $(10 \mathrm{~mL})$, the solvent was evaporated at $0.01 \mathrm{mbar} / 20{ }^{\circ} \mathrm{C}$, and the solid betaine was triturated with dry ether $(10 \mathrm{~mL})$ and dried $\left(0.01 \mathrm{mbar} / 60{ }^{\circ} \mathrm{C}, 4 \mathrm{~h}\right)$ : highly hygroscopic, beige powdery solid $(0.81 \mathrm{~g}, 78 \%$ yield based on $2 \mathbf{a}) .-{ }^{1} \mathrm{H}$ NMR $\left(\mathrm{D}_{2} \mathrm{O}\right)$ : two species, $\mathbf{A}: \mathbf{B}=6: 4, \delta=$ $1.55-1.69$ (several $\mathrm{m}, 1.0 \mathrm{H}$, ring-5- $\mathrm{H}^{\mathrm{ax}}(\mathbf{A})$, ring-4- $\mathrm{H}^{\text {ax }}$ (B)), $1.76-1.95$ (several $\mathrm{m}, 2.0 \mathrm{H}$, ring-5- $\mathrm{H}^{\mathrm{eq}}$, ring-4- $\mathrm{H}^{\text {ax }}$ (A), ring-5 $\left.-\mathrm{H}_{2}(\mathbf{B})\right), 2.03-2.11\left(\mathrm{~m}, 0.6 \mathrm{H}\right.$, ring-4- $\left.\mathrm{H}^{\mathrm{eq}}(\mathbf{A})\right)$, 2.16-2.24 (m, 0.4 H, ring-4- $\left.\mathrm{H}^{\mathrm{eq}}(\mathbf{B})\right), 2.42(\mathrm{~m}, 0.4 \mathrm{H}$, ring3-H (B)), 2.66 (m, 0.6 H, ring-3-H (A)), 2.93-3.10 (several s, $12.0 \mathrm{H}, \mathrm{NCH}_{3}(\mathbf{A}, \mathbf{B})$ ), 3.10-3.24 (several m, $0.8 \mathrm{H}$, ring-2- $\mathrm{H}^{\mathrm{ax}}$ and $\left.-6-\mathrm{H}^{\mathrm{ax}}(\mathbf{B})\right), 3.24-3.40$ (several $\mathrm{m}, 1.8 \mathrm{H}$, ring $2-\mathrm{H}^{\mathrm{ax}}, 6-\mathrm{H}_{2}(\mathbf{A})$ ), $3.51-3.60$ (several $\mathrm{m}, 1.4 \mathrm{H}$, ring-2$\mathrm{H}^{\mathrm{eq}}(\mathbf{A})$, ring-2- $\left.\mathrm{H}^{\mathrm{eq}},-6-\mathrm{H}^{\mathrm{eq}}(\mathbf{B})\right) .-{ }^{13} \mathrm{C}$ NMR $\left(\mathrm{D}_{2} \mathrm{O}\right)$ : two species $\mathbf{A}$ and $\mathbf{B}, \delta=23.45$ (ring-C-5 (B)); 23.98 (ring-C5 (A)); 27.16 (ring-C-4 (A)); 27.87 (ring-C-4 (B)); 39.12, 39.25, 39.49, 39.69, $40.00\left(\mathrm{NCH}_{3}(\mathbf{A}, \mathbf{B})\right) ; 43.18$ (ring-C-3 (A)), 45.28 (ring-C-3 (B)), 48.64 (ring-C-6 (B)), 48.89 (ringC-6 (A)), 51.06 (ring-C-2 (A)), 51.41 (ring-C-2 (B)), 162.94 $\left(\mathrm{CN}_{3}(\mathbf{A}, \mathbf{B})\right), 181.41(\mathrm{COO}(\mathbf{A}, \mathbf{B}))$. $-\mathrm{MS}(\mathrm{ESI}): \mathrm{m} / \mathrm{z}(\%)=$ $228.08(100)[\mathrm{M}+\mathrm{H}]^{+}$.

\section{1-[Bis(dimethylamino)methylene]piperidinium 4-carboxyl- ate $(7 \boldsymbol{b})$}

Prepared from the crude solution of $\mathbf{5 b}$ in acetonitrile as described for 7a. Very hygroscopic, colorless powdery solid $(0.87 \mathrm{~g}, 76 \%$ yield based on $\mathbf{2 b}) .-{ }^{1} \mathrm{H}$ NMR $\left(\mathrm{D}_{2} \mathrm{O}\right): \delta=1.63$ (dddd, ${ }^{2} J=13.5 \mathrm{~Hz},{ }^{3} J=11,10$ and $4 \mathrm{~Hz}, 1 \mathrm{H}, 3-\mathrm{H}^{\mathrm{ax}}$ ), 1.85 (dddd, ${ }^{2} J=13.5 \mathrm{~Hz},{ }^{3} J=11,10$ and $4 \mathrm{~Hz}, 1 \mathrm{H}, 5-\mathrm{H}^{\mathrm{ax}}$ ), 1.98 (dddd, ${ }^{2} J=13.5 \mathrm{~Hz},{ }^{3} J=4,4$ and $3 \mathrm{~Hz}, 1 \mathrm{H}, 3-\mathrm{H}^{\mathrm{eq}}$ ), 2.02 (dddd, ${ }^{2} J=13.5 \mathrm{~Hz},{ }^{3} J=4,4$ and $3 \mathrm{~Hz}, 1 \mathrm{H}, 3-\mathrm{H}^{\mathrm{eq}}$ ), 2.50 (tt, ${ }^{3} J=10$ and $\left.4 \mathrm{~Hz}, 1 \mathrm{H}, 4-\mathrm{H}\right), 2.94\left(\mathrm{~s}, 3 \mathrm{H}, \mathrm{NCH}_{3}\right), 2.96$ (s, $\left.3 \mathrm{H}, \mathrm{NCH}_{3}\right), 2.97$ (s, $\left.3 \mathrm{H}, \mathrm{NCH}_{3}\right), 3.05$ (s, $3 \mathrm{H}, \mathrm{NCH}_{3}$ ), 3.18 (ddd, ${ }^{2} J=13 \mathrm{~Hz},{ }^{3} J=11$ and $3 \mathrm{~Hz}, 1 \mathrm{H}, \mathrm{NCH}^{\mathrm{ax}}$ ), 3.25 (ddd, ${ }^{2} J=13 \mathrm{~Hz},{ }^{3} J=11$ and $3 \mathrm{~Hz}, 1 \mathrm{H}, \mathrm{NCH}^{\mathrm{ax}}$ ), 3.48 (ddd, ${ }^{2} J=13 \mathrm{~Hz},{ }^{3} J=4$ and $\left.4 \mathrm{~Hz}, 1 \mathrm{H}, \mathrm{NCH}^{\mathrm{eq}}\right), 3.58$ (ddd, ${ }^{2} J=$ $13 \mathrm{~Hz},{ }^{3} \mathrm{~J}=4$ and $\left.4 \mathrm{~Hz}, 1 \mathrm{H}, \mathrm{NCH}^{\mathrm{eq}}\right) .-{ }^{13} \mathrm{C}$ NMR: Table 1.

\section{1-[(Dibutylamino)(diethylamino)methylene]piperidinium 3-carboxylate $(8 a)$}

Prepared from the crude solution of $\mathbf{6 a}$ in acetontrile as described for 7a. Very hygroscopic, beige powdery solid (1.35 g, $80 \%$ yield based on 2a). $-{ }^{1} \mathrm{H}$ NMR $\left(\mathrm{D}_{2} \mathrm{O}\right)$ : two species, $\mathbf{A}: \mathbf{B}=6: 4, \delta=0.94-0.99\left(\mathrm{~m}, 6 \mathrm{H}\right.$, butyl- $\mathrm{CH}_{3}$ (A, B)), $1.18-1.25\left(\mathrm{~m}, 6 \mathrm{H}\right.$, ethyl- $\left.\mathrm{CH}_{3}(\mathbf{A}, \mathbf{B})\right), 1.26-1.42$ (m, $4 \mathrm{H}$, butyl-3- $\mathrm{H}_{2}(\mathbf{A}, \mathbf{B})$ ), $1.44-1.82$ (several m, $5.4 \mathrm{H}$, ring-4- $\mathrm{H}^{\mathrm{ax}}(\mathbf{A})$, ring-4- $\mathrm{H}^{\mathrm{ax}},-5-\mathrm{H}^{\mathrm{ax}}(\mathbf{B})$, butyl-2- $\left.\mathrm{H}_{2}(\mathbf{A}, \mathbf{B})\right)$, $1.82-1.97$ (several $\mathrm{m}, 1.6 \mathrm{H}$, ring-5- $\mathrm{H}_{2}(\mathbf{A})$, ring-5- $\mathrm{H}^{\mathrm{eq}}(\mathbf{B})$ ), $2.08\left(\mathrm{~d}, 0.6 \mathrm{H}\right.$, ring-4- $\left.\mathrm{H}^{\text {eq }}(\mathbf{A})\right), 2.21\left(\mathrm{~d}, 0.4 \mathrm{H}\right.$, ring-4- $\mathrm{H}^{\text {eq }}$ (B)), $2.41\left(\mathrm{~m}, 0.4 \mathrm{H}\right.$, ring- $\left.\mathrm{NCH}_{2} \mathrm{CH}(\mathbf{B})\right), 2.65(\mathrm{~m}, 0.6 \mathrm{H}$, ring- $\mathrm{NCH}_{2} \mathrm{CH}(\mathbf{A})$ ), $3.08-3.64$ (several $\mathrm{m}, 12 \mathrm{H}$, ring-2$\mathrm{H}_{2}, 6-\mathrm{H}_{2}(\mathbf{A}, \mathbf{B})$, butyl- $\left.\mathrm{NCH}_{2}(\mathbf{A}, \mathbf{B}), \mathrm{NCH}_{2} \mathrm{CH}_{3}(\mathbf{A}, \mathbf{B})\right)$. ${ }^{13} \mathrm{C}$ NMR $\left(\mathrm{D}_{2} \mathrm{O}\right)$ : two species $\mathbf{A}$ and $\mathbf{B}, \delta=11.84,11.95$, 12.08, 12.14, 12.17, 12.22 (ethyl- $\mathrm{CH}_{3}(\mathbf{A}, \mathbf{B})$ ); 12.97, 13.03, 13.07 (butyl- $\mathrm{CH}_{3}$ (A, B)); 19.48, 19.54, 19.57 (butyl-C-3 $(\mathbf{A}, \mathbf{B})$ ); 23.14, 23.27 (ring-C-5 (B)); 23.77, 23.85 (ringC-5 (A)); 27.08, 27.17 (ring-C-4 (A)); 27.85, 27.94 (ringC-4 (B)); 28.75, 28.85, 28.95, 28.99, 29.01, 29.10, 29.18 (butyl-C-2 (A, B)); 42.76, 42.88 (ring-C-3 (A)); 43.04, 43.09, $43.63,43.73,43.83,43.86,43.91,44.15\left(\mathrm{NCH}_{2} \mathrm{CH}_{3}(\mathbf{A}\right.$, B)); 44.86, 44.90 (ring-C-3 (B)); 48.56, 48.70, 49.00, 49.15, 49.30, 49.41, 49.47, 49.58, 49.69 (ring-C-6 (A, B); butyl$\left.\mathrm{NCH}_{2}(\mathbf{A}, \mathbf{B})\right) ; 51.52,51.72,51.78,51.80$ (ring-C-2 (A, B)); $163.11,163.16\left(\mathrm{CN}_{3}(\mathbf{A}, \mathbf{B})\right) ; 180.77,180.87,181.24(\mathrm{COO}$ (A, B)).

\section{1-[(Dibutylamino $)($ diethylamino $)$ methylene ]piperidinium 4-carboxylate $(8 \boldsymbol{b})$}

Prepared from the crude solution of $\mathbf{6 b}$ in acetonitrile as described for $\mathbf{7 a}$. Very hygroscopic, beige powdery solid $(1.39 \mathrm{~g}, 82 \%$ based on $2 \mathrm{~b}) .-{ }^{1} \mathrm{H}$ NMR $\left(\mathrm{D}_{2} \mathrm{O}\right): \delta=0.94-$ $0.99\left(\mathrm{~m}, 6 \mathrm{H}\right.$, butyl- $\left.\mathrm{CH}_{3}\right), 1.18-1.25\left(\mathrm{~m}, 6 \mathrm{H}\right.$, ethyl- $\left.\mathrm{CH}_{3}\right)$, $1.30-1.42\left(\mathrm{~m}, 4 \mathrm{H}\right.$, butyl-3- $\left.\mathrm{H}_{2}\right), 1.45-1.78$ (m, $5 \mathrm{H}$, butyl$\left.2-\mathrm{H}_{2}, \mathrm{NCH}_{2} \mathrm{CH}^{\mathrm{ax}}\right), 1.86-1.95\left(\mathrm{~m}, 1 \mathrm{H}, \mathrm{NCH}_{2} \mathrm{CH}^{\mathrm{ax}}\right), 1.98-$ $2.09\left(\mathrm{~m}, 2 \mathrm{H}, \mathrm{NCH}_{2} \mathrm{CH}^{\mathrm{eq}}\right), 2.47-2.53(\mathrm{~m}, 1 \mathrm{H}$, ring-4$\mathrm{H}), 3.11-3.52\left(\mathrm{~m}, 11 \mathrm{H}\right.$, butyl- $\mathrm{NCH}_{2}$, ethyl- $\mathrm{NCH}_{2}, 3$ ring$\mathrm{NCH}), 3.60-3.66$ (m, $1 \mathrm{H}$, ring- $\mathrm{NCH}) .-{ }^{13} \mathrm{C}$ NMR: Table 1.

\section{Alkaline hydrolysis of betaine $\mathbf{7 b}$}

Aqueous $\mathrm{NaOH}(2 \mathrm{M}, 2 \mathrm{~mL})$ was added to a solution of betaine $7 \mathbf{b}(0.253 \mathrm{~g}, 1.11 \mathrm{mmol})$ in demineralized water 
$(5 \mathrm{~mL})$. After stirring for $1 \mathrm{~h}$, the solvent was evaporated at $0.01 \mathrm{mbar} / 40{ }^{\circ} \mathrm{C}$. The solid residue was triturated with dry ether $(10 \mathrm{~mL})$ to remove residual tetramethylurea and dissolved in water. After neutralization with dilute aqueous $\mathrm{HCl}$, the solution was evaporated to dryness $\left(0.01 \mathrm{mbar} / 80{ }^{\circ} \mathrm{C}\right.$, $3 \mathrm{~h})$. According to the ${ }^{1} \mathrm{H}$ NMR spectra, the solid contained 1-(dimethylcarbamoyl)piperidine-4-carboxylic acid (9) [24] and piperidine-4-carboxylic acid (1b) in a 77:23 ratio. NMR data of 9: ${ }^{1} \mathrm{H}$ NMR $\left(\mathrm{D}_{2} \mathrm{O}\right): \delta=1.51-1.61$ and $1.83-$ $1.92\left(2 \mathrm{~m}_{\mathrm{c}}\right.$, each $\left.2 \mathrm{H}, 3,5-\mathrm{H}_{2}\right), 2.52-2.57\left(\mathrm{~m}_{\mathrm{c}}, 1 \mathrm{H}, 4-\mathrm{CH}\right)$, $2.78\left(\mathrm{~s}, 3 \mathrm{H}, \mathrm{NCH}_{3}\right), 2.79$ (s, $\left.3 \mathrm{H}, \mathrm{NCH}_{3}\right), 2.89$ (ddd, $2 \mathrm{H}$, $\left.\mathrm{NCH}^{\mathrm{ax}}\right), 3.68\left(\mathrm{dt}, 2 \mathrm{H}, \mathrm{NCH}^{\mathrm{eq}}\right) .-{ }^{13} \mathrm{C} \mathrm{NMR}\left(\mathrm{D}_{2} \mathrm{O}\right): \delta=$ $28.90(\mathrm{C}-3,5), 38.09\left(\mathrm{~N}\left(\mathrm{CH}_{3}\right)_{2}\right), 44.57$ (C-4), 46.44 (C-2,6), $166.02\left(\mathrm{CN}_{3}\right), 184.48(\mathrm{COO})$.

\section{1-[Bis(dimethylamino)methylene]piperidinium chloride (10)}

Under an argon atmosphere, dry piperidine $(0.8 \mathrm{~mL}$, $0.69 \mathrm{~g}, 8.1 \mathrm{mmol}$ ) was added to a solution of salt 3 in acetonitrile $(6.6 \mathrm{~mL}, 0.91 \mathrm{~mol} / \mathrm{kg}, 5.50 \mathrm{~g}, 5.0 \mathrm{mmol})$. After stirring for $20 \mathrm{~h}$, the solvent was evaporated at $0.01 \mathrm{mbar} /$ $30{ }^{\circ} \mathrm{C}$, and the residue was dissolved in demineralized water $(5 \mathrm{~mL})$. After neutralization of piperidinium chloride with $2 \mathrm{M}$ aqeous $\mathrm{NaOH}(4 \mathrm{~mL})$, water and piperidine were evaporated at $0.01 \mathrm{mbar} / 40{ }^{\circ} \mathrm{C}$. The solid residue was triturated with $2 \times 5 \mathrm{~mL}$ pentane and dried $\left(0.01 \mathrm{mbar} / 80^{\circ} \mathrm{C}, 5 \mathrm{~h}\right)$. Very hygroscopic, colorless powdery solid $(0.79 \mathrm{~g}, 89 \%$ yield based on piperidine), m. p. $173-175{ }^{\circ} \mathrm{C} .-{ }^{1} \mathrm{H}$ NMR $\left(\mathrm{D}_{2} \mathrm{O}\right)$ : $\delta=1.52-1.76$ (several m, $\left.6 \mathrm{H}, 3-, 4-, 5-\mathrm{H}_{2}\right), 2.87$ (s, $6 \mathrm{H}$, $\left.\mathrm{N}\left(\mathrm{CH}_{3}\right)_{2}\right), 2.91\left(\mathrm{~s}, 6 \mathrm{H}, \mathrm{N}\left(\mathrm{CH}_{3}\right)_{2}\right), 3.14-3.32\left(\mathrm{~m}_{\mathrm{c}}, 2-, 6-\right.$ $\left.\mathrm{H}_{2}\right) .-{ }^{13} \mathrm{C} \mathrm{NMR}\left(\mathrm{D}_{2} \mathrm{O}\right): \delta=23.19(\mathrm{C}-4), 24.83(\mathrm{C}-3,5)$; $39.24,39.38\left(\mathrm{~N}^{\left.\left(\mathrm{CH}_{3}\right)_{2}\right)}\right.$; $49.28(\mathrm{C}-2,6), 162.80\left(\mathrm{CN}_{3}\right)$.

\section{4,4'-[Methylenebis(oxycarbonyl)]-bis $\{1$-[bis(dimethyl- amino)methylene]piperidinium $\}$ dichloride (11)}

A suspension of betaine $7 \mathbf{b}(0.455 \mathrm{~g}, 2.0 \mathrm{mmol})$ in dry dichloromethane $(20 \mathrm{~mL})$ was stirred for $72 \mathrm{~h}$. At this point, most of the betaine was consumed, and further reaction appeared not to take place. The residual betaine was removed by filtration under an argon atmosphere, and the solution was evaporated to dryness at $0.01 \mathrm{mbar} / 20{ }^{\circ} \mathrm{C}$ to leave a very hygroscopic, colorless powdery solid ( $0.398 \mathrm{~g})$, which consisted of dicationic salt 11 contaminated with about $8-10 \%$ of betaine $\mathbf{7 b}$. Due to similar solubilities, complete separation of the two components was not possible, but a small sample enriched in $\mathbf{1 1}$ could be obtained by repeated trituration with $\mathrm{CH}_{2} \mathrm{Cl}_{2}$. Spectroscopic data of 11: ${ }^{1} \mathrm{H} N M R\left(\mathrm{D}_{2} \mathrm{O}\right)$ : $\delta=1.74\left(\mathrm{~m}_{\mathrm{c}}, 2 \mathrm{H}, \mathrm{NCH}_{2} \mathrm{CH}^{\mathrm{ax}}\right), 1.93\left(\mathrm{~m}_{\mathrm{c}}, 2 \mathrm{H}, \mathrm{NCH}_{2} \mathrm{CH}^{\mathrm{ax}}\right)$, $2.12\left(\mathrm{~m}_{\mathrm{c}}, 4 \mathrm{H}, \mathrm{NCH}_{2} \mathrm{CH}^{\mathrm{eq}}\right), 2.87\left(\mathrm{~m}_{\mathrm{c}}, 2 \mathrm{H}\right.$, ring-4-H); 2.96, 2.97, 2.98 and $3.04\left(4 \mathrm{~s}\right.$, each $\left.6 \mathrm{H}, \mathrm{NCH}_{3}\right) ; 3.27\left(\mathrm{~m}_{\mathrm{c}}, 4 \mathrm{H}\right.$, $\left.\mathrm{NCH}^{\mathrm{ax}}\right), 3.50\left(\mathrm{~m}_{\mathrm{c}}, 2 \mathrm{H}, \mathrm{NC} H^{\mathrm{eq}}\right), 3.60\left(\mathrm{~m}_{\mathrm{c}}, 2 \mathrm{H}, \mathrm{NC} H^{\mathrm{eq}}\right)$, $5.90\left(\mathrm{~s}, 2 \mathrm{H}, \mathrm{OCH}_{2} \mathrm{O}\right) .-{ }^{13} \mathrm{C} \mathrm{NMR}\left(\mathrm{D}_{2} \mathrm{O}\right): \delta=26.36,27.33$ $(\mathrm{C}-3,5) ; 39.18,39.51\left(\mathrm{~N}\left(\mathrm{CH}_{3}\right)_{2}\right) ; 39.85(\mathrm{C}-4) ; 47.33,47.52$ $(\mathrm{C}-2,6) ; 80.42\left(\mathrm{OCH}_{2} \mathrm{O}\right), 162.92\left(\mathrm{CN}_{3}\right), 175.05(\mathrm{COO})$. MS (ESI): $m / z(\%)=505.36(33)[\text { cation }]^{2+}+{ }^{37} \mathrm{Cl}^{-}, 503.33$ (100) $[\text { cation] }]^{2+}+{ }^{35} \mathrm{Cl}^{-}, 453.36(13), 423.36$ (5).

\section{Thermal analysis}

Efforts to characterize the thermal behavior of betaines $\mathbf{7}$ and 8 by differential scanning calorimetry (DSC) were hampered by a partial hydrolysis at elevated temperatures. For example, betaine $\mathbf{7 b}$ was submitted to three heating cycles up to $250{ }^{\circ} \mathrm{C}$ with a heating rate of $10{ }^{\circ} \mathrm{C} \mathrm{min}-1$. A ${ }^{1} \mathrm{H}$ NMR spectrum of the sample then indicated the presence of betaine $\mathbf{7 b}(75 \%)$, acid $\mathbf{9}(22 \%)$ and tetramethylurea (3\%). Therefore, qualitative observations were made on betaine samples which were kept in a Schlenk flask under vacuum (0.01 mbar) and heated with an external oil bath. The thermal stability of the salts was determined by thermogravimetric analysis using a Mettler-Toledo TGA/SDTA 851 instrument. The temperature was increased linearly at $10{ }^{\circ} \mathrm{C}$ $\min ^{-1}$ unter nitrogen from 25 to $800{ }^{\circ} \mathrm{C}$.

\section{Acknowledgements}

This work was supported by a grant from the Bundesministerium für Bildung und Forschung (BMBF). We thank Prof. Willi Kantlehner (Hochschule Aalen) for samples of chloroformamidinium salts.
[1] F. J. de Zwart, S. Slow, R. J. Payne, M. Lever, P. M. George, J. A. Gerrard, S. T. Chambers, Food Chem. 2003, 83, 197-204.

[2] a) L. N. Csonka, Microbiol. Rev. 1989, 53, 121 -147; b) M. Ashraf, M. R. Foolad, Environ. Exp. Bot. 2006, 59, 206-216; c) T. H. H. Chen, N. Murata, Trends in Plant Science 2008, 13, 499-505; d) J. M. Wood, Microbiol. Mol. Biol. Rev. 1999, 63, 230-262.

[3] a) W. Henke, K. Herdel, K. Jung, D. Schnorr, S. A. Loening, Nucleic Acids Res. 1997, 25, 3957-3958; b) M. Ralser, R. Querfurth, H.-J. Warnatz, H. Lehrach, M.-L. Yaspo, S. Krobitsch, Biochem. Biophys. Res. Commun. 2006, 347, 747-751.

[4] K. Koumoto, H. Ochiai, N. Sugimoto, Tetrahedron 2008, 64, $168-174$.

[5] L. Rigano, G. Dell'Acqua, R. Leporatti, Cosmetics \& Toiletries 2000, 115, 47-54.

[6] E. G. Lomax (ed.), Amphoteric Surfactants, $2^{\text {nd }}$ ed., Surfactant Science Series 59, Marcel Dekker, New York, 1996. 
[7] H. Kunkel, G. Maas, Eur. J. Org. Chem. 2007, $3746-$ 3757.

[8] a) J. Cardoso, A. Huanosta, O. Manero, Macromolecules 1991, 24, 2890-2895; b) M. Galin, A. Mathis, J.-C. Galin, Polym. Adv. Technol. 2001, 12, 574-582, and refs. cited therein.

[9] a) M. Yoshizawa, M. Hirao, K. Ito-Akita, H. Ohno, J. Mater. Chem. 2001, 11, 1057-1062; b) M. Yoshizawa, A. Narita, H. Ohno, Aust. J. Chem. 2004, 57, 139 - 144; c) M. Yoshizawa, H. Ohno, Chem. Lett. 2004, 33, 1594-1595; d) account: H. Ohno, Bull. Chem. Soc. Jpn. 2006, 79, $1665-1680$; e) J. N. Krishnan, H. S. Kim, J. K. Lee, B.-W. Cho, E. J. Roh, S.-G. Lee, Bull. Kor. Chem. Soc. 2008, 29, $1705-1710$.

[10] J. Sha, J. Liebscher, Synthesis 2008, 917-920.

[11] a) W. Kantlehner, E. Haug, W. W. Mergen, P. Speh, T. Maier, J. J. Kapassakalidis, H.-J. Bräuner, Synthesis 1983, 904-905; b) W. Kantlehner, E. Haug, W. W. Mergen, P. Speh, J. J. Kapassakalidis, H.J. Bräuner, H. Hagen, Liebigs Ann. Chem. 1984, $108-126$.

[12] T. Isobe, T. Ishikawa, J. Org. Chem. 1999, 64, $6984-$ 6988.

[13] N. Tamura, Y. Matsushita, T. Iwama, S. Harada, S. Kishimoto, K. Itoh, Chem. Pharm. Bull. 1991, 39, 1199 1212.

[14] J. Alfaro-Lopez, T. Okayama, K. Hosohata, P. Davis, F. Porreca, H. Yamamura, V. J. Hruby, J. Med. Chem. 1999, 42, 5359-5368.

[15] H. Lecher, F. Graf, Liebigs Ann. Chem. 1924, 438, $154-169$.

[16] a) N. M. M. Mateus, L.C. Branco, M. M. T. Lourenço, C. A. M. Afonso, Green Chem. 2003, 5, 347-352; b) P.S. Kulkarni, L.C. Branco, J. G. Crespo, M. C. Nunes, A. Raymundo, C. A. M. Afonso, Chem. Eur. J. 2007, 13, $8478-8488$.

[17] R. B. Homer, K. W. Alwis, J. Chem. Soc., Perkin Trans. 2 1976, $781-784$.

[18] H.-B. König, W. Schröck, K.-G. Metzger, H. Disselkötter, Ger. Offen. DE2104579 (A1), 1972.

[19] J. Hine, S. J. Ehrenson, W. H. Brader, J. Am. Chem. Soc. 1956, 78, $2282-2284$.

[20] J. G. Atkinson, D. W. Cillis, R. S. Stuart, Can. J. Chem. 1969, 47, $477-479$.

[21] K. T. Sloan, US 19630326, 1965.

[22] a) H. Kessler, D. Leibfritz, Chem. Ber. 1971, 104, 2158 -2169; b) A. V. Santoro, G. Mickevicius, J. Org. Chem. 1979, 44, 117-120.

[23] Hexamethylguanidinium ion: a) X. Zhang, R. Bau, J.A. Sheehy, K.O. Christe, J. Fluorine Chem. 1999, 98, 121-126; b) A. A. Kolomeitsev,G. Bissky, J. Barten, N. Kalinovich, E. Lork, G.-V. Röschenthaler, Inorg. Chem. 2002, 41, 6118-6124; c) G.-V. Röschenthaler, E. Lork, G. Bissky, A. A. Kolomeitsev, Z. Krist. - New Cryst. Struct. 2002, 217, 419-420; d) W. Frey, M. Vettel, K. Edelmann, W. Kantlehner, Z. Krist. - New Cryst. Struct. 1998, 213, 77-78. For selected other hexa-substituted guanidinium ions, see: e) W. Nakanishi, A. Ogino, M. Kawahata, K. Yamaguchi, T. Ishikawa, Tetrahedron Lett. 2007, 48, 85268530; f) M. Tanaka, H.-U. Siehl, T. Viefhaus, W. Frey, W. Kantlehner, Z. Naturforsch. 2009, 64b, 765-772.

[24] A synthesis of the methyl ester of 9 from methyl piperidine-4-carboxylate and $N, N$-dimethylcarbamoyl chloride has been reported: H.L. Yale, K. Losee, J. Martins, M. Holsing, F. M. Perry, J. Bernstein, J. Am. Chem. Soc. 1953, 75, 1933 - 1942. 